\title{
PROSES MATEMATISASI SISWA SMP DALAM MENYELESAIKAN MASALAH KONTEKSTUAL DITINJAU DARI KEMAMPUAN MATEMATIKA
}

\author{
Iim Mufadilatul Chasanah \\ Pendidikan Matematika, FMIPA, Universitas Negeri Surabaya, email : iimchasanah16030174032@mhs.unesa.ac.id
}

Pradnyo Wijayanti

Pendidikan Matematika, FMIPA, Universitas Negeri Surabaya, email : pradnyowijayanti@unesa.ac.id

\begin{abstract}
Abstrak
Kemampuan matematika yang dimiliki setiap siswa dapat mempengaruhi proses matematisasi siswanya dalam menyelesaikan masalah kontekstual. Dengan mengetahui proses matematisasi yang dilakukan siswa, guru dapat memahami apa yang dibutuhkan siswa dalam menyelesaikan masalah. Tujuan penelitian ini adalah untuk mendeskripsikan proses matematisasi siswa SMP dalam menyelesaikan masalah kontekstual ditinjau dari kemampuan matematika. Penelitian ini merupakan penelitian yang menggunakan pendekatan deskriptif kualitatif. Subjek dalam penelitian ini terdiri dari tiga siswa SMP kelas IX. Data ini diperoleh dari tes kemampuan matematika, tes matematisasi dan tes wawancara. Hasil penelitian proses matematisasi siswa SMP dalam menyelesaikan masalah matematika ditinjau dari kemampuan matematika menunjukkan bahwa siswa dengan kemampuan matematika tinggi, sedang dan rendah dapat menerjemahkan masalah dunia nyata ke dalam masalah matematika, serta dapat menyelesaikan masalah matematika menggunakan konsep dan keterampilan matematika yang sudah dikuasai. Namun terdapat perbedaan pada tahapan merefleksi dan menvalidasi proses yang sudah dilakukan dan hasil yang sudah didapat, hanya siswa dengan kemampuan matematika tinggi yang dapat melakukannya. Siswa dengan kemampuan matematika sedang tidak mengkritisi model dan batasannya pada tahapan merefleksi dan menvalidasi proses yang sudah dilakukan dan hasil yang sudah didapat. Sedangkan siswa dengan kemampuan matematika rendah tidak merefleksi argumen matematis dan tidak menjelaskan hasil, tidak mengomunikasikan proses dan hasil, dan tidak mengkritisi model dan batasannya pada tahapan merefleksi dan menvalidasi proses yang sudah dilakukan dan hasil yang sudah didapat.

Kata Kunci : Kemampuan Matematika, Proses Matematisasi, Masalah Kontekstual.
\end{abstract}

\section{Abstract}

Mathematical abilities possessed by each student can affect the mathematical process of students in solving contextual problems. By knowing the mathematical process carried out by students, teachers can understand what students need in solving problems. The purpose of this research was to describe the mathematical process of junior high school students in solving contextual problems in terms of their mathematical abilities. This research is a research that uses a qualitative descriptive approach. The subjects in this study consisted of three third grade junior high school students. This data is obtained from math ability tests, mathematical tests and interview tests. The results of research on the mathematical process of junior high school students in solving math problems in terms of mathematical abilities show that students with high, medium and low math abilities can translate real-world problems into math problems, and can solve math problems using mathematical concepts and skills that have been mastered. However there are differences in the stages of reflecting on and validating the processes that have been carried out and the results that have been obtained, only students with high mathematical abilities can do it. Students with moderate mathematical abilities do not criticize the model and its limitations at the stage of reflecting on and validating the processes that have been carried out and the results that have been obtained. Meanwhile, students with low math abilities do not reflect on mathematical arguments and do not explain results, do not communicate processes and results, and do not criticize the model and its limitations at the stage of reflecting on and validating the processes that have been carried out and the results that have been obtained. Keywords: Mathematical Ability, Mathematization Process, Contextual Problem.

\section{PENDAHULUAN}

Matematika merupakan salah satu disiplin ilmu yang memiliki tujuan meningkatkan kompetensi sikap, pengetahuan, dan keterampilan sebagai dasar kehidupan bermasyarakat (Kemendikbud, 2014). Berdasarkan tujuan tersebut, maka materi matematika dalam pembelajaran harus dikaitkan langsung dengan kehidupan sehari-hari siswa. Hal ini sejalan dengan penelitian Yuniawatika (2016) yang mengungkapkan bahwa matematika itu dekat dengan kehidupan sehari-hari siswa.

Menurut Freudenthal, terdapat pandangan penting mengenai matematika yang berkaitan dengan realitas yaitu matematika harus dihubungkan dengan kehidupan sehari- 
hari siswa dan matematika sebagai aktivitas manusia yang artinya bahwa proses matematisasi terjadi apabila siswa belajar matematika (Freudenthal, 2002).

Matematisasi dapat didefinisikan sebagai suatu proses untuk mematematikakan suatu fenomena (Wijaya, 2012). Menurut Vom Hofe dkk (dalam Prediger, 2011), "mathematizing - the step in the modelling cycle in which the transformation from a real-world situation into a mathematical problem is conducted." Berdasarkan pendapat Vom Hofe tersebut, matematisasi didefinisikan sebagai transformasi dari situasi dunia nyata ke dalam masalah matematika melalui suatu siklus yang dinamakan siklus pemodelan. Ada juga yang berpendapat mengenai matematisasi sebagai aktivitas mengorganisasikan ide dan konsep matematika dengan menggunakan pengetahuan dan keterampilan awal dalam menemukan hubungan (relations), keteraturan (regularities), dan struktur (structures) (De Lange, 1987). Selain itu Roux berpendapat bahwa matematisasi merupakan aplikasi konsep, prosedur, dan metode yang dikembangkan dalam matematika untuk objek disiplin ilmu yang lain atau berbagai bidang pengetahuan yang lain (Roux, 2010). Matematisasi juga bisa dianggap sebagai proses dasar yang digunakan siswa dalam menyelesaikan masalah kehidupan nyata. Hal tersebut sesuai dengan pernyataan PISA (OECD, 2009:105), "In PISA, the fundamental process that students use to solve real-life problems is referred to as mathematisation". Berdasarkan definisi-definisi di atas, matematisasi dalam penelitian ini didefinisikan sebagai aktivitas mengorganisasikan ide dan konsep matematika dengan pengetahuan dan keterampilan awal siswa dalam menemukan hubungan (relations), keteraturan (regularities), dan struktur (structures) yang belum diketahui melalui suatu siklus pemodelan.

Siklus pemodelan yang dimaksud yaitu proses matematisasi. Dalam proses matematisasi, terjadi proses menetapkan konsep dari suatu fenomena atau memodelkan suatu fenomena dengan matematis (Wardono, 2017). Pada proses matematisasi, siswa berperan sebagai penerima aktif sehingga siswa diharapkan dapat mengembangkan potensi matematikanya sendiri (Hadi, 2002). Selain itu, siswa juga dituntut untuk membangun atau mengembangkan model matematika dari model yang telah dibentuk sebelumnya dengan pengetahuan yang dimiliki (Warsito, 2018).

Proses matematisasi menurut PISA (dalam OECD, 2009) terbagi menjadi 3 (tiga) tahapan, yaitu menerjemahkan masalah dunia nyata ke dalam masalah matematika, menyelesaikan masalah matematika menggunakan konsep dan keterampilan matematika yang sudah dikuasai, serta merefleksi dan menvalidasi proses dan hasil. Pada proses matematisasi, masing-masing tahapan memiliki beberapa indikator yang harus dicapai siswa. Indikator tersebut dikembangkan peneliti dari indikator proses matematisasi PISA (dalam OECD, 2009) sebagai berikut.

Tabel 1. Indikator Proses Matematisasi

\begin{tabular}{|c|c|}
\hline $\begin{array}{c}\text { Proses } \\
\text { Matematisasi }\end{array}$ & Indikator \\
\hline \multirow{6}{*}{$\begin{array}{l}\text { Menerjemahkan } \\
\text { masalah dunia } \\
\text { nyata ke dalam } \\
\text { masalah } \\
\text { matematika }\end{array}$} & $\begin{array}{l}\text { Mengidentifikasi } \\
\text { matematika yang relevan dengan } \\
\text { masalah dunia nyata }\end{array}$ \\
\hline & $\begin{array}{l}\text { Merepresentasikan masalah } \\
\text { dengan berbagai cara yang } \\
\text { berbeda, termasuk mengorganisasi } \\
\text { masalah sesuai dengan konsep } \\
\text { matematika yang relevan, serta } \\
\text { merumuskan asumsi yang tepat }\end{array}$ \\
\hline & $\begin{array}{l}\text { Memahami hubungan antara } \\
\text { bahasa yang ada dalam masalah } \\
\text { dengan simbol dan bahasa formal } \\
\text { matematika supaya masalah nyata } \\
\text { bisa dipahami secara matematis }\end{array}$ \\
\hline & $\begin{array}{ll}\text { Menemukan } & \text { keteraturan, } \\
\text { hubungan, dan pola } & \end{array}$ \\
\hline & $\begin{array}{l}\text { Mengenali aspek-aspek yang } \\
\text { isomorfik dengan masalah yang } \\
\text { diketahui }\end{array}$ \\
\hline & $\begin{array}{l}\text { Menerjemahkan masalah ke dalam } \\
\text { bentuk matematika yaitu dalam } \\
\text { bentuk model matematika }\end{array}$ \\
\hline \multirow{3}{*}{$\begin{array}{l}\text { Menyelesaikan } \\
\text { masalah } \\
\text { matematika } \\
\text { menggunakan }\end{array}$} & Menggunakan berbagai \\
\hline & $\begin{array}{l}\text { representasi matematis yang } \\
\text { berbeda }\end{array}$ \\
\hline & $\begin{array}{l}\text { Menggunakan simbol, bahasa dan } \\
\text { proses matematika formal }\end{array}$ \\
\hline \multirow[t]{3}{*}{$\begin{array}{l}\text { konsep dan } \\
\text { keterampilan } \\
\text { matematika yang } \\
\text { sudah dikuasai }\end{array}$} & $\begin{array}{l}\text { Melakukan penyesuaian dan } \\
\text { pengembangan } \\
\text { matematika, mengombinasikan } \\
\text { dan menggabungkan berbagai } \\
\text { model }\end{array}$ \\
\hline & Argumentasi \\
\hline & Generalisasi \\
\hline \multirow{4}{*}{$\begin{array}{l}\text { Merefleksi dan } \\
\text { menvalidasi } \\
\text { proses yang sudah } \\
\text { dilakukan dan } \\
\text { hasil yang sudah } \\
\text { didapat }\end{array}$} & $\begin{array}{l}\text { Memahami perluasan dan } \\
\text { keterbatasan konsep matematika }\end{array}$ \\
\hline & $\begin{array}{l}\text { Merefleksi argumen matematis } \\
\text { dan menjelaskan hasil }\end{array}$ \\
\hline & $\begin{array}{l}\text { Mengomunikasikan proses dan } \\
\text { hasil }\end{array}$ \\
\hline & Mengkritisi model dan batasannya \\
\hline
\end{tabular}

Dalam tahapan proses matematisasi tersebut, juga mencakup matematisasi horizontal dan matematisasi vertikal menurut Treffers dan Goffree (dalam De Lange, 1987). Hal ini dikarenakan aktivitas yang ada dalam matematisasi horizontal menurut Treffers dan Goffree, sama dengan aktivitas yang ada dalam tahap pertama proses matematisasi menurut PISA. Sedangkan aktivitas yang ada dalam matematisasi vertikal menurut Treffers dan Goffree, sama dengan aktivitas yang ada dalam tahap 
kedua proses matematisasi menurut PISA. Sehingga proses matematisasi menurut PISA memiliki hubungan dengan matematisasi menurut Treffers dan Goffree. Pada penelitian ini, proses matematisasi dalam menyelesaikan masalah lebih penting dibandingkan dengan jawaban yang didapat dari menyelesaikan masalah. Hal ini dikarenakan proses matematisasi memiliki karakter siklik (Jupri, 2016), yang artinya bahwa proses tersebut terjadi secara berulangulang (Suryaningsih, 2017).

Masalah dalam penelitian ini menggunakan masalah kontekstual. Hal ini dikarenakan masalah kontekstual memiliki keterkaitan dengan kehidupan sehari-hari (Jayanti, 2018). Penggunaan masalah kontekstual dalam penelitian ini akan memberikan peluang terjadinya proses matematisasi. Sesuai pendapat Wijaya (2012:32) yaitu "Proses matematisasi akan terjadi jika konteks bisa dibayangkan oleh siswa serta memungkinkan siswa untuk memahami dan bekerja dalam konteks tersebut dengan menggunakan pengetahuan dan pengalaman yang sudah mereka miliki". Dengan demikian, masalah yang dapat dibayangkan oleh siswa serta memungkinkan siswa untuk memahami masalah tersebut adalah masalah kontekstual.

Dalam menyelesaikan masalah kontekstual, siswa mengorganisasikan ide dan konsep matematika dengan pengetahuan dan keterampilan yang dimiliki. Pengetahuan dan keterampilan yang dimaksud adalah kemampuan matematika. Kemampuan matematika sendiri berkaitan langsung dengan apa yang diketahui siswa meliputi prosedur-prosedur, fakta-fakta, pemahaman tentang konsep dan pengetahuan mengenai cara mengaplikasikan. Hal tersebut sesuai pernyataan Schoenfeld (2004) yang menjelaskan bahwa kemampuan matematika memiliki keterkaitan dengan proses matematisasi, dimana kemampuan matematika yang berupa pengetahuan dan keterampilan, dapat digunakan siswa untuk menemukan hubungan (relations), keteraturan (regularities), dan struktur (structures) dalam melakukan matematisasi.

Dalam penelitian ini, kemampuan matematika dikategorikan menjadi tinggi, sedang, dan rendah. Hal ini dilakukan agar peneliti fokus mengetahui bagaimana siswa dalam kategori-kategori kemampuan tersebut. Acuan pengklasifikasian kemampuan matematika disusun berdasarkan pedoman acuan patokan yang diungkapkan Ratumanan dan Laurens (2003) serta disesuaikan dengan standar ketuntasan minimum (SKM) yang ditentukan sekolah yaitu nilai skor tes $<75$ dikategorikan siswa dengan kemampuan matematika rendah, nilai $75 \leq$ skor tes $<85$ dikategorikan siswa dengan kemampuan matematika sedang, dan nilai $85 \leq$ skor tes $\leq 100$ dikategorikan siswa dengan kemampuan matematika tinggi.
Berdasarkan laporan PISA 2018 (Revina, 2019), ratarata skor siswa yang berusia 15 tahun di Indonesia adalah 379 untuk kemampuan matematika. Sedangkan rata-rata skor negara yang mengikuti PISA yaitu 489. Hal ini menunjukkan skor kemampuan matematika Indonesia pada tahun 2018 di bawah rata-rata. Sedangkan pada tahun 2015, laporan PISA menyatakan bahwa Indonesia mendapatkan rata-rata skor kemampuan matematika lebih tinggi yaitu 386. Siswa yang berusia 15 tahun berdasarkan Permendikbud di Indonesia sedang menempuh pendidikan di jenjang SMP (Kemendikbud, 2018). Dari pembahasan tersebut, disimpulkan bahwa kemampuan matematika pada jenjang SMP pada tahun 2018 lebih rendah jika dibandingkan dengan tahun 2015.

Banyak aspek yang mempengaruhi capaian belajar siswa dalam studi PISA salah satunya kualitas guru. Berdasarkan laporan PISA 2018 (Revina, 2019), terdapat beberapa kualitas guru di Indonesia yang mampu menghambat proses belajar siswa salah satunya yaitu guru tidak mengetahui kebutuhan siswa ketika belajar. Berdasarkan uraian tersebut, dapat dipahami bahwa guru dapat membantu siswa belajar dengan memahami kebutuhan belajar siswa itu sendiri. Hal ini sesuai penjelasan Emda (2017) yang menjelaskan bahwa memahami kebutuhan siswa dapat membuat siswa terdorong untuk belajar. Sebagai pendidik, guru memiliki peran besar dalam membantu siswa dalam menyelesaikan masalah, termasuk masalah kontekstual. Terdapat cara yang bisa digunakan untuk membantu siswa dalam menyelesaikan masalah kontekstual salah satunya yaitu dengan mengamati proses matematisasi yang dilakukan siswa. Setiap siswa memiliki kemampuan yang berbedabeda dalam melakukan proses matematisasi, sehingga guru disini harus bisa memahami kebutuhan setiap siswanya. Oleh karena itu, dengan memahami proses matematisasi siswa maka guru dapat memahami kebutuhan belajar siswa tersebut.

Hasil penelitian yang relevan dengan penelitian ini yaitu penelitian Putri (2018)_dengan judul "Profil Matematisasi Horizontal dan Vertikal Siswa SMA dalam Menyelesaikan Soal Program Linier Ditinjau dari Kemampuan Matematika". Penelitian yang dilakukan Putri menggunakan pendapat matematisasi dari De Lange, fokus penelitian yang dilakukan mengenai profil matematisasi siswa, subjek yang digunakan merupakan siswa SMA serta materi yang digunakan adalah program linier. Sedangkan dalam penelitian ini menggunakan pendapat matematisasi menurut PISA, subjek yang digunakan merupakan siswa SMP serta materi yang digunakan adalah materi SPLDV. Pemilihan materi SPLDV berdasarkan pertimbangan bahwa materi ini sering dijumpai dalam kehidupan nyata (Rohim, 2018), sehingga materi ini bisa memberikan peluang terjadinya proses matematisasi. Hal yang relevan 
terdapat pada soal yang digunakan merupakan soal adopsi dan tinjauan penelitian yang digunakan yaitu kemampuan matematika. Penelitian lain yang relevan yaitu penelitian yang dilakukan Amala (2016) yang berjudul "Profil Proses Matematisasi Horizontal Dan Vertikal Siswa Smp dalam Menyelesaikan Masalah Kontekstual Pecahan Ditinjau Dari Kemampuan Matematika". Penelitian yang dilakukan Amala menggunakan pendapat matematisasi dari Treffers dan Goffree, soal yang digunakan merupakan soal yang dibuat sendiri serta materi yang digunakan adalah pecahan. Sedangkan dalam penelitian ini menggunakan pendapat matematisasi menurut PISA, soal yang digunakan merupakan soal adopsi serta materi yang digunakan adalah materi SPLDV. Hal yang relevan terdapat pada fokus penelitian yaitu tentang menjelaskan mengenai proses matematisasi siswa, subjek penelitian yang digunakan siswa SMP dan tinjauan penelitian yang digunakan yaitu kemampuan matematika.

Berdasarkan uraian di atas, dapat dijelaskan tujuan penelitian ini yaitu (1) Mendeskripsikan proses matematisasi siswa SMP berkemampuan matematika tinggi dalam menyelesaikan masalah kontekstual (2) Mendeskripsikan proses matematisasi siswa SMP berkemampuan matematika sedang dalam menyelesaikan masalah kontekstual (3) Mendeskripsikan proses matematisasi siswa SMP berkemampuan matematika rendah dalam menyelesaikan masalah kontekstual.

\section{METODE}

Jenis penelitian ini merupakan penelitian dengan pendekatan deskriptif kualitatif. Proses pada penelitian deskriptif yaitu mencatat, mendeskripsikan, menganalisis, dan mengintepresentasikan kejadian-kejadian yang sedang terjadi (Siswono, 2010). Hal ini sesuai tujuan dalam penelitian ini yaitu untuk mendeskripsikan proses matematisasi siswa.

Penelitian dilakukan di Sekolah yang menerapkan Kurikulum 2013. Subjek penelitian dalam penelitian ini yaitu siswa SMP kelas IX. Pemilihan subjek penelitian kelas IX dikarenakan sudah mendapatkan materi mengenai SPLDV. Kriteria subjek penelitian yaitu siswa dengan kemampuan matematika tinggi, sedang, dan rendah. Untuk memperoleh data dilakukan tes tulis dan wawancara. Tes tulis meliputi tes kemampuan matematika dan tes matematisasi. Tes kemampuan matematika dilakukan ketika memilih subjek penelitian. Tes ini berisi soal-soal essay yang materi soalnya sudah dipelajari siswa kelas IX. Tes matematisasi digunakan untuk mengetahui bagaimana siswa dengan kemampuan matematika yang berbeda dapat menyelesaikan masalah kontektual. Tes ini menggunakan masalah kontekstual yang berhubungan dengan materi SPLDV. Tes matematisasi diberikan setelah subjek penelitian terpilih berdasarkan kemampuan matematikanya. Tes wawancara digunakan untuk mendapatkan informasi yang belum tampak pada tes matematisasi siswa. Tes ini dilakukan setelah siswa menyelesaikan tes matematisasi. Data hasil tes matematisasi dianalisis sesuai dengan indikator proses matematisasi yang sudah dikembangkan peneliti dari indikator proses matematisasi PISA. Sedangkan data hasil tes wawancara dianalisis menggunakan teknik analisis data kualitatif mulai dari pereduksian data, penyajian data, dan penarikan kesimpulan.

\section{HASIL DAN PEMBAHASAN}

Tes kemampuan matematika (TKM), tes matematisasi (TM) dan wawancara dilakukan siswa SMP Negeri 1 Kemlagi kelas IX pada tanggal 29 Juli 2020 - 29 Agustus 2020. Berdasarkan hasil TKM diperoleh tiga subjek penelitian dengan kemampuan matematika yang berbeda.

Tabel 2. Subjek Penelitian

\begin{tabular}{|c|c|c|c|}
\hline Nama & $\begin{array}{c}\text { Hasil } \\
\text { TKM }\end{array}$ & $\begin{array}{c}\text { Kategori Kemampuan } \\
\text { Matematika }\end{array}$ & Kode \\
\hline DK & 88 & Tinggi & ST \\
\hline ANRAS & 76 & Sedang & SS \\
\hline EWW & 35 & Rendah & SR \\
\hline
\end{tabular}

Subjek penelitian yang terpilih selanjutnya diberikan tes matematisasi (TM), kemudian melakukan tes wawancara. Berikut akan dipaparkan mengenai hasil tes matematisasi dan hasil tes wawancara yang sudah dilakukan siswa.

Proses Matematisasi Siswa Berkemampuan Matematika Tinggi dalam Menyelesaikan Masalah Kontekstual

1. Menerjemahkan masalah dunia nyata ke dalam masalah matematika

Siswa berkemampuan matematika tinggi (ST) dapat mengidentifikasi informasi-informasi dan dapat mengidentifikasi konsep SPLDV yang relevan dengan masalah. Siswa juga menjelaskan kembali masalah yang diberikan menggunakan bahasanya sendiri kemudian mengungkapkan mengenai rancangan penyelesaian. Selanjutnya, Siswa menunjukkan hubungan bahasa dalam soal dengan simbol dan bahasa formal matematika dengan cara membuat permisalan, seperti buku dimisalkan $x$ dan pensil dimisalkan $y$. Kemudian siswa menemukan hubungan antar simbol sehingga dapat mengetahui bagaimana cara merumuskan model. Siswa dapat mengenali aspek-aspek yang sama dengan masalah yang diketahui sebelumnya yaitu tentang mencari harga. 


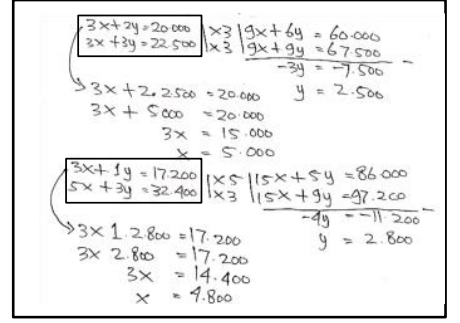

Gambar 1. Lembar Jawaban ST

Berdasarkan Gambar 1, siswa menuliskan model matematika yang sudah didapatkan, kemudian siswa langsung mengerjakannya. Hal ini menunjukkan bahwa ST dapat menerjemahkan masalah dunia nyata ke dalam model matematika. Berdasarkan proses matematisasi tahap pertama didukung juga dengan gambar, siswa berkemampuan matematika tinggi dapat mencapai semua indikator pada proses matematisasi tahap pertama.

\section{Menyelesaikan masalah matematika menggunakan konsep dan keterampilan matematika yang sudah dikuasai}

Dalam menyelesaikan masalah, ST menggunakan dua cara yaitu eliminasi dan subtitusi.

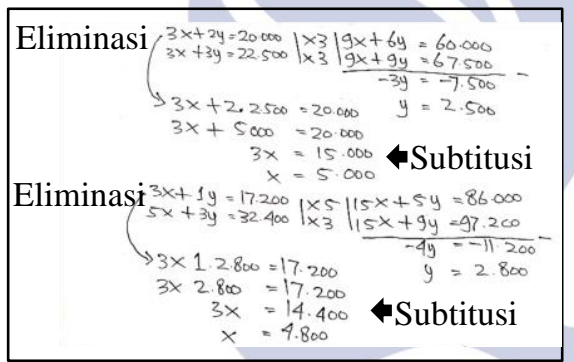

Gambar 2. Lembar Jawaban ST

Berdasarkan Gambar 2, siswa dapat menggunakan simbol-simbol matematika, bahasa matematika dan proses matematika formal. Siswa tidak merevisi model matematika yang sudah didapatkan. Selanjutnya siswa memberikan agumen dengan yakin bahwa jawaban yang sudah didapatkan adalah benar. Hal ini juga didukung dengan jawaban siswa pada lembar jawaban yang sudah benar. Siswa juga meyakini bahwa apabila diberikan masalah yang berbeda dengan topik yang sama, maka ia dapat menyelesaikannya. Berdasarkan proses matematisasi tahap kedua didukung juga dengan gambar, siswa dengan kemampuan matematika tinggi dapat mencapai semua indikator pada proses matematisasi tahap kedua.

3. Merefleksi dan menvalidasi proses yang sudah dilakukan dan hasil yang sudah didapat

Dalam tahap ini, ST memberikan argumennya mengenai perluasan dan batasan konsep yang digunakan dengan jelas melalui wawancara berikut.

\begin{tabular}{|c|c|}
\hline Peneliti & $\begin{array}{l}\text { : Selain konsep SPLDV, adakah konsep } \\
\text { matematika lainnya yang digunakan } \\
\text { dalam menyelesakan masalah ini?"” }\end{array}$ \\
\hline ST & $\begin{array}{l}\text { : Ada kak. Seperti konsep persamaan, } \\
\begin{array}{l}\text { pembagian, } \\
\text { penjumlahan" }\end{array}\end{array}$ \\
\hline
\end{tabular}

Berdasarkan hasil wawancara tersebut, siswa menjelaskan bahwa terdapat beberapa konsep matematika dalam masalah ini. Hal ini menunjukkan ST memahami perluasan dan batasan konsep yang digunakan. Selanjutnya siswa merefleksi argumen yang sudah dilakukan sebelumnya mengenai kebenaran jawaban dan menjelaskan hasil yang sudah didapatkan. Siswa juga mengomunikasikan proses penyelesaian masalah sampai mendapatkan hasil. Kemudian siswa memberikan tanggapan mengenai model matematika dan konsep matematika yang sudah didapat. Berdasarkan proses matematisasi tahap ketiga didukung juga dengan cuplikan hasil wawancara, siswa berkemampuan matematika tinggi dapat mencapai semua indikator pada proses matematisasi tahap ketiga.

Proses Matematisasi Siswa Berkemampuan Matematika Sedang dalam Menyelesaikan Masalah Kontekstual

1. Menerjemahkan masalah dunia nyata ke dalam masalah matematika

Siswa berkemampuan matematika sedang (SS) dapat mengidentifikasi informasi-informasi dan dapat mengidentifikasi konsep matematika SPLDV yang relevan dengan masalah. Selanjutnya siswa menjelaskan kembali masalah yang diberikan dan mengungkapkan mengenai rancangan penyelesaian. Siswa juga memahami hubungan bahasa pada soal dengan simbol dan bahasa formal matematika melalui permisalan. Kemudian siswa menemukan keteraturan, hubungan dan pola dengan merumuskan model matematika. Siswa juga mengenali aspek-aspek yang sama yaitu dalam menentukan harga dari suatu barang.

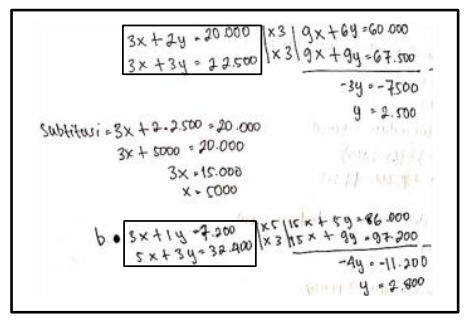

Gambar 3. Lembar Jawaban SS

Pada Gambar 3, menunjukkan bahwa SS mendapatkan model matematika setelah membuat permisalan. Setelah model matematika didapatkan, 
siswa kemudian langsung mengerjakannya. Berdasarkan proses matematisasi tahap pertama didukung juga dengan gambar, siswa dengan kemampuan matematika sedang dapat mencapai semua indikator pada proses matematisasi tahap pertama.

2. Menyelesaikan masalah matematika menggunakan konsep dan keterampilan matematika yang sudah dikuasai

Pada proses penyelesaian masalah, SS menggunakan dua cara yaitu eliminasi dan subtitusi. Siswa juga menggunakan simbol-simbol matematika, bahasa matematika dan proses matematika formal, namun pada proses matematika formal siswa melakukan kesalahan.

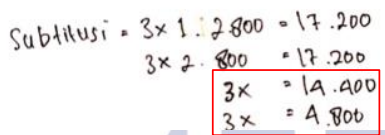

Gambar 4. Kesalahan SS pada soal (a)

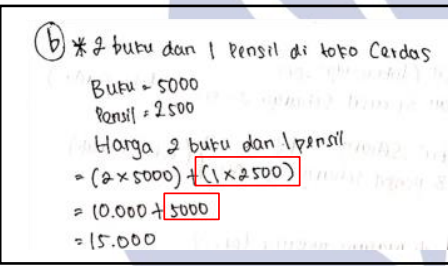

Gambar 5. Kesalahan SS pada soal (b)

Berdasarkan Gambar 4, SS melakukan kesalahan pada soal (a) ketika mencari nilai $x$. Sedangkan pada Gambar 5, SS melakukan kesalahan pada soal (b) ketika menghitung harga pensil di Toko Cerdas. Siswa juga tidak merevisi model matematika yang sudah didapatkan. Selanjutnya siswa memberikan agumen bahwa jawaban yang diperoleh benar karena ia menyelesaikan masalah sesuai pengetahuannya. Siswa juga meyakini bahwa ia dapat menyelesaikan masalah dengan topik yang sama. Berdasarkan proses matematisasi tahap kedua didukung juga dengan gambar, siswa dengan kemampuan matematika sedang dapat mencapai semua indikator pada proses matematisasi tahap kedua.

3. Merefleksi dan menvalidasi proses yang sudah dilakukan dan hasil yang sudah didapat

Siswa dengan kemampuan matematika sedang (SS) memahami perluasan dan keterbatasan konsep matematika. Hal ini didukung dengan cuplikan wawancara berikut ini.

\begin{tabular}{|c|c|}
\hline \multirow[t]{3}{*}{ Peneliti } & : “Menurut kamu, konsep matematika apa \\
\hline & saja yang digunakan dalam \\
\hline & menyelesaikan masalah tersebut?" \\
\hline SS & : "SPLDV sama operasi matematika” \\
\hline
\end{tabular}

Hasil wawancara menunjukkan bahwa SS memahami perluasan dan keterbatasan konsep yang digunakan dalam soal yaitu konsep SPLDV dan operasi matematika. Siswa juga menjelaskan mengenai perluasan dan keterbatasan konsep yang digunakan. Selanjutnya siswa menjelaskan mengenai hasil yang sudah didapatkan dengan jelas. Siswa juga mengomunikasikan bagaimana proses yang sudah dilakukan sampai mendapatkan hasil. Namun, siswa tidak mengkritisi model dan batasan. Berdasarkan proses matematisasi tahap ketiga didukung juga dengan cuplikan hasil wawancara, siswa dengan kemampuan matematika sedang dapat mencapai indikator pada proses matematisasi tahap ketiga namun hanya beberapa indikator.

Proses Matematisasi Siswa Berkemampuan Matematika Rendah dalam Menyelesaikan Masalah Kontekstual

1. Menerjemahkan masalah dunia nyata ke dalam masalah matematika

Siswa berkemampuan matematika rendah (SR) dapat mengidentifikasi informasi-informasi dan dapat mengidentifikasi konsep matematika SPLDV yang relevan dengan masalah. Selanjutnya siswa menjelaskan kembali masalah yang diberikan dan mengungkapkan mengenai rancangan penyelesaian. Selanjutnya siswa memahami bahasa yang ada dalam masalah dengan simbol dan bahasa formal matematika melalui permisalan yang sudah dibuat. Siswa juga menemukan keteraturan, hubungan dan pola dengan cara menunjukkan bagaimana cara merumuskan model matematika. Kemudian siswa mengenali aspek-aspek yang sama pada soal yaitu tentang menentukan harga.

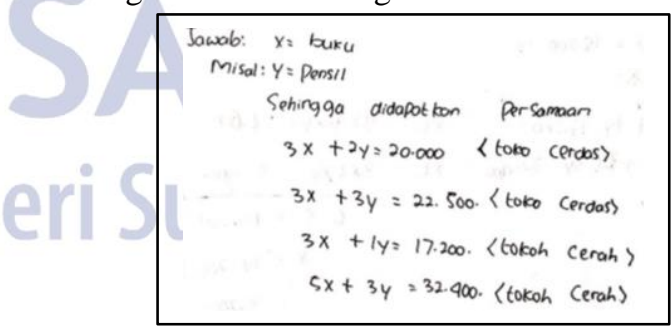

Gambar 6. Lembar Jawaban SR

Berdasarkan Gambar 6, SR mendapatkan beberapa model matematika yang dituliskan dalam bentuk persamaan. Dari model matematika tersebut, dapat diketahui bahwa SR dapat menerjemahkan masalah ke dalam bentuk matematika. Berdasarkan proses matematisasi tahap pertama didukung juga dengan gambar, siswa berkemampuan matematika rendah dapat mencapai semua indikator pada proses matematisasi tahap pertama. 
2. Menyelesaikan

masalah menggunakan konsep dan matematika yang sudah dikuasai

Setelah mendapatkan model matematika, SR kemudian menyelesaikan masalah menggunakan cara eliminasi dan subtitusi. Selanjutnya, SR menggunakan simbol-simbol matematika, bahasa matematika dan proses matematika formal untuk menyelesaikan masalah, namun pada proses matematika formal siswa melakukan beberapa kesalahan.

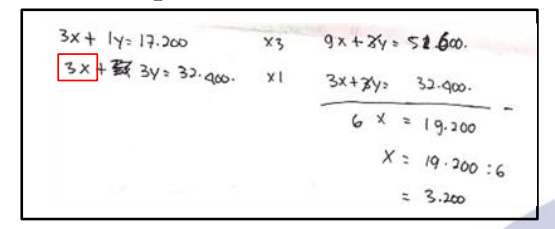

Gambar 7. Kesalahan SR pada soal (a)

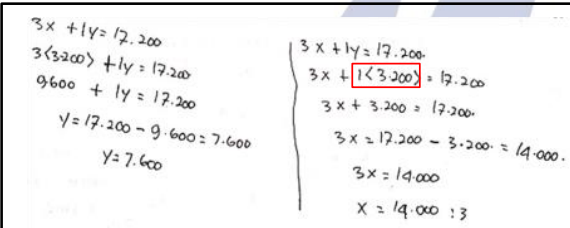

Gambar 8. Kesalahan SR pada soal (a)

Berdasarkan Gambar 7, SR melakukan kesalahan pada proses matematika formal dengan menuliskan persamaan yang seharusnya $5 x+3 y=32.400$ ditulis menjadi $3 x+3 y=32.400$. Sedangkan pada Gambar 8, SR mensubtitusikan nilai $x$ pada $y$ sehingga SR tidak mendapatkan jawaban. Kemudian SR menuliskan kembali persamaan dan mensubtitusikan nilai $x$ pada $x$. Siswa juga tidak merevisi model matematika yang sudah didapatkan. Kemudian siswa memberikan agumen mengenai jawaban yang didapatkan sudah benar. Namun, berdasarkan hasil yang didapatkan siswa melakukan beberapa kesalahan sehingga terdapat jawaban yang kurang tepat. Siswa juga meyakini dapat menyelesaikan masalah dengan topik yang sama apabila diberikan soal kembali. Berdasarkan proses matematisasi tahap kedua didukung juga dengan gambar, siswa dengan kemampuan matematika rendah dapat mencapai semua indikator pada proses matematisasi tahap kedua.

3. Merefleksi dan menvalidasi proses yang sudah dilakukan dan hasil yang sudah didapat

Setelah menyelesaikan permasalahan, SR selanjutnya memberikan argumen mengenai perluasan dan batasan konsep yang digunakan dalam masalah yang diberikan melalui cuplikan wawancara berikut.

Peneliti : " Menurut kamu, konsep matematika apa saja yang digunakan dalam menyelesaikan masalah tersebut?"
SR : “ SPLDV, penjumlahan, pengurangan, pembagian, dan perkalian"

Hasil wawancara menunjukkan bahwa SR memberikan penjelasan mengenai konsep matematika yang digunakan yaitu konsep SPLDV, Penjumlahan, Pengurangan, Pembagian, dan Perkalian. Siswa juga memberikan argumen mengenai perluasan dan keterbatasan konsep yang digunakan. Selanjutnya siswa tidak merefleksi argumen dan tidak menjelaskan hasil, tidak mengomunikasikan mengenai proses yang sudah dilakukan dan hasil yang didapat, tidak mengkritisi model dan batasannya. Berdasarkan proses matematisasi tahap ketiga didukung juga dengan cuplikan hasil wawancara, siswa berkemampuan matematika rendah dapat mencapai indikator proses matematisasi tahap ketiga namun hanya beberapa indikator.

\section{Pembahasan}

Berdasarkan hasil analisis yang dilakukan peneliti, dapat dipaparkan mengenai proses matematisasi siswa sebagai berikut.

Siswa berkemampuan matematika tinggi dapat melakukan semua tahapan proses matematisasi antara lain tahap menerjemahkan masalah dunia nyata ke dalam masalah matematika, tahap menyelesaikan masalah matematika menggunakan konsep dan keterampilan matematika yang sudah dikuasai dan tahap merefleksi dan menvalidasi proses dan hasil. Hal ini sesuai penelitian Amala (2016) yang mengungkapkan bahwa siswa berkemampuan matematika tinggi melalui semua aktivitas proses matematisasi. Berdasakan hal tersebut, maka siswa berkemampuan matematika tinggi memiliki pengetahuan dan keterampilan yang tinggi pula dalam mengorganisasikan ide dan konsep matematika untuk menemukan hubungan (relations), keteraturan (regularities), dan struktur (structures) ketika menyelesaikan masalah kontekstual. Hal ini sesuai penelitian Putri (2018) yang menjelaskan bahwa siswa berkemampuan matematika tinggi memiliki kinerja tinggi juga ketika memahami dan mengaplikasikan fakta-fakta, konsep-konsep, serta prosedur-prosedur.

Siswa berkemampuan matematika sedang hanya dapat melakukan beberapa tahapan proses matematisasi antara lain tahap menerjemahkan masalah dunia nyata ke dalam masalah matematika dan tahap menyelesaikan masalah matematika menggunakan konsep dan keterampilan matematika yang sudah dikuasai. Pada tahap merefleksi dan menvalidasi proses dan hasil, siswa tidak mengkritisi model dan batasan. Hal ini sesuai penelitian Amala (2016) yang mengungkapkan bahwa siswa berkemampuan matematika sedang tidak melalui semua aktivitas proses 
matematisasi. Berdasarkan hal tersebut, maka siswa berkemampuan matematika sedang memiliki pengetahuan dan keterampilan yang sedang pula dalam mengorganisasikan ide dan konsep matematika untuk menemukan hubungan (relations), keteraturan (regularities), dan struktur (structures) ketika menyelesaikan masalah kontekstual. Hal ini sejalan dengan pendapat Putri (2018) yang menjelaskan bahwa siswa berkemampuan matematika sedang memiliki kinerja sedang juga ketika memahami dan mengaplikasikan faktafakta, konsep-konsep, serta prosedur-prosedur.

Siswa berkemampuan matematika rendah hanya dapat melakukan beberapa tahapan proses matematisasi antara lain tahap menerjemahkan masalah dunia nyata ke dalam masalah matematika dan tahap menyelesaikan masalah matematika menggunakan konsep dan keterampilan matematika yang sudah dikuasai. Pada tahap merefleksi dan menvalidasi proses dan hasil, siswa tidak merefleksi argumen dan tidak menjelaskan hasil, tidak mengomunikasikan mengenai proses yang sudah dilakukan dan hasil yang didapat, tidak mengkritisi model dan batasannya. Hal ini sesuai dengan pendapat Amala (2016) yang menjelaskan bahwa siswa berkemampuan matematika rendah tidak melaui semua aktivitas proses matematisasi. Pada proses matematisasi tahap ketiga, dari empat indikator siswa berkemampuan matematika rendah hanya dapat mencapai satu indikator saja. Hal ini menjelaskan bahwa siswa berkemampuan matematika rendah memiliki pengetahuan dan keterampilan yang rendah pula dalam mengorganisasikan ide dan konsep matematika untuk menemukan hubungan (relations), keteraturan (regularities), dan struktur (structures) ketika menyelesaikan masalah kontekstual. Hal ini sesuai pendapat Putri (2018) yang mengungkapkan bahwa siswa berkemampuan matematika rendah memiliki kinerja rendah juga ketika memahami dan mengaplikasikan faktafakta, konsep-konsep, serta prosedur-prosedur ketika.

Representasi hasil analisis pada proses matematisasi sebagai berikut.

Tabel 3. Proses Matematisasi Siswa

\begin{tabular}{|c|c|c|c|c|}
\hline \multirow{2}{*}{$\begin{array}{c}\text { Proses } \\
\text { Matematisasi }\end{array}$} & \multirow[b]{2}{*}{ Indikator } & \multicolumn{3}{|c|}{ Subjek } \\
\hline & & & $\begin{array}{l}\mathrm{S} \\
\mathrm{S}\end{array}$ & \\
\hline \multirow{2}{*}{$\begin{array}{l}\text { Menerjemahkan } \\
\text { masalah dunia } \\
\text { nyata ke dalam } \\
\text { masalah } \\
\text { matematika }\end{array}$} & $\begin{array}{l}\text { Mengidentifikasi konsep } \\
\text { matematika SPLDV yang } \\
\text { relevan dengan masalah } \\
\text { dunia nyata }\end{array}$ & $\checkmark$ & $\checkmark$ & $\checkmark$ \\
\hline & $\begin{array}{l}\text { Merepresentasikan } \\
\text { masalah dengan berbagai } \\
\text { cara yang berbeda, } \\
\text { termasuk mengorganisasi } \\
\text { masalah sesuai dengan } \\
\text { konsep matematika }\end{array}$ & $\checkmark$ & $\checkmark$ & $\checkmark$ \\
\hline
\end{tabular}

\begin{tabular}{|c|c|c|c|c|}
\hline \multirow{8}{*}{$\begin{array}{c}\text { Proses } \\
\text { Matematisasi }\end{array}$} & \multirow{3}{*}{ Indikator } & \multicolumn{3}{|c|}{ Subjek } \\
\hline & & & \multirow{3}{*}{$\begin{array}{l}\mathbf{S} \\
\mathbf{S}\end{array}$} & \multirow{3}{*}{$\begin{array}{l}\mathbf{S} \\
\mathbf{R}\end{array}$} \\
\hline & & & & \\
\hline & $\begin{array}{l}\text { SPLDV yang relevan, } \\
\text { serta merumuskan asumsi } \\
\text { yang tepat }\end{array}$ & & & \\
\hline & $\begin{array}{l}\text { Memahami hubungan } \\
\text { antara bahasa yang ada } \\
\text { dalam masalah dengan } \\
\text { simbol dan bahasa formal } \\
\text { matematika supaya } \\
\text { masalah nyata bisa } \\
\text { dipahami } \\
\text { matematis }\end{array}$ & $\checkmark$ & $\checkmark$ & $\checkmark$ \\
\hline & $\begin{array}{l}\text { Menemukan keteraturan, } \\
\text { hubungan, dan pola }\end{array}$ & $\checkmark$ & $\checkmark$ & $\checkmark$ \\
\hline & $\begin{array}{l}\text { Mengenali aspek-aspek } \\
\text { yang isomorfik dengan } \\
\text { masalah yang diketahui }\end{array}$ & $\checkmark$ & $\checkmark$ & $\checkmark$ \\
\hline & $\begin{array}{l}\text { Menerjemahkan masalah } \\
\text { ke dalam bentuk } \\
\text { matematika yaitu dalam } \\
\text { bentuk model matematika }\end{array}$ & $\checkmark$ & $\checkmark$ & $\checkmark$ \\
\hline $\begin{array}{l}\text { Menyelesa } \\
\text { masalah } \\
\text { matematik }\end{array}$ & $\begin{array}{lr}\text { Menggunakan } & \text { berbagai } \\
\text { representasi } & \text { matematis } \\
\text { yang berbeda } & \\
\end{array}$ & $\checkmark$ & $\checkmark$ & $\checkmark$ \\
\hline mengguna & Menggunakan simbol, & $\checkmark$ & $\checkmark$ & $\checkmark$ \\
\hline konsep & bahasa dan proses & & & \\
\hline keterampilan & matematika formal & & & \\
\hline $\begin{array}{l}\text { matematika } \\
\text { yang s } \\
\text { dikuasai }\end{array}$ & $\begin{array}{l}\text { Melakukan penyesuaian } \\
\text { dan pengembangan model } \\
\text { matematika, } \\
\text { mengombinasikan dan } \\
\text { menggabungkan berbagai } \\
\text { model }\end{array}$ & $\checkmark$ & $\checkmark$ & $\checkmark$ \\
\hline & Argumentasi & $\checkmark$ & $\checkmark$ & $\checkmark$ \\
\hline & Generalisasi & $\checkmark$ & $\checkmark$ & $\checkmark$ \\
\hline $\begin{array}{l}\text { Merefleksi dan } \\
\text { menvalidasi } \\
\text { proses yang }\end{array}$ & $\begin{array}{l}\text { Memahami perluasan dan } \\
\text { keterbatasan konsep } \\
\text { matematika SPLDV }\end{array}$ & $\checkmark$ & $\checkmark$ & $\checkmark$ \\
\hline $\begin{array}{l}\text { sudah dilakukan } \\
\text { dan hasil yang } \\
\text { sudah didapat }\end{array}$ & $\begin{array}{l}\text { Merefleksi argumen } \\
\text { matematis dan } \\
\text { menjelaskan hasil }\end{array}$ & $\checkmark$ & $\checkmark$ & $x$ \\
\hline & $\begin{array}{l}\text { Mengomunikasikan } \\
\text { proses dan hasil }\end{array}$ & $\checkmark$ & $\checkmark$ & $x$ \\
\hline & $\begin{array}{l}\text { Mengkritisi model dan } \\
\text { batasannya }\end{array}$ & $\checkmark$ & $x$ & $x$ \\
\hline
\end{tabular}

Keterangan:

$\checkmark$ : Menyatakan indikator sudah dicapai siswa.

$\times$ : Menyatakan indikator belum dicapai siswa.

Berdasarkan pembahasan di atas, dapat disimpulkan bahwa kemampuan matematika yang berbeda mempengaruhi siswa dalam mengorganisasikan ide dan 
konsep matematika ketika menemukan hubungan (relations), keteraturan (regularities), dan struktur (structures). Dalam hal ini, mengorganisasikan ide dan konsep matematika dengan menggunakan pengetahuan dan keterampilan awal ketika menemukan hubungan (relations), keteraturan (regularities), dan struktur (structures) merupakan aktivitas dalam proses matematisasi (De Lange, 1987). Sedangkan pengetahuan dan keterampilan awal yang dimaksud merupakan kemampuan matematika. Hal ini didukung pernyataan Schoenfeld (2004) yang menjelaskan bahwa kemampuan matematika yang dimiliki setiap siswa memiliki keterkaitan dengan yang diketahui meliputi prosedurprosedur, fakta-fakta, pemahaman tentang konsep dan pengetahuan mengenai cara mengaplikasikan. Berdasarkan pembahasan tersebut, dapat diambil kesimpulan bahwa kemampuan matematika setiap siswa dapat mempengaruhi proses matematisasinya dalam menyelesaikan masalah kontekstual.

\section{PENUTUP}

\section{Simpulan}

Berdasarkan hasil penelitian dan pembahasan dapat diperoleh simpulan bahwa proses matematisasi siswa SMP dalam menyelesaikan masalah kontekstual ditinjau dari kemampuan matematika, siswa dengan kemampuan matematika tinggi, sedang dan rendah dapat menerjemahkan masalah dunia nyata ke dalam masalah matematika. Setelah menerjemahkan permasalahan, siswa dapat menyelesaikan masalah matematika menggunakan konsep dan keterampilan matematika yang sudah dikuasai. Namun terdapat perbedaan pada tahapan merefleksi dan menvalidasi proses yang sudah dilakukan dan hasil yang sudah didapat, hanya siswa dengan kemampuan matematika tinggi yang dapat melakukannya. Siswa dengan kemampuan matematika sedang tidak mengkritisi model dan batasannya pada tahapan merefleksi dan menvalidasi proses dan hasil. Sedangkan siswa dengan kemampuan matematika rendah tidak merefleksi argumen matematis dan tidak menjelaskan hasil, tidak mengomunikasikan proses dan hasil, dan tidak mengkritisi model dan batasannya pada tahapan merefleksi dan menvalidasi proses dan hasil.

\section{Saran}

Berdasarkan hasil pembahasan, peneliti dapat memberikan saran sebagai berikut.

1. Setiap siswa memiliki kemampuan matematika yang berbeda. Sedangkan kemampuan matematika dapat mempengaruhi siswa dalam melakukan proses matematisasi. Oleh karena itu, guru harus lebih memahami siswa ketika melakukan proses matematisasi sehingga guru dapat mengetahui apa yang dibutuhkan siswa.

2. Berdasarkan hasil penelitian, siswa berkemampuan matematika sedang dan rendah tidak dapat mengkritisi apa yang sudah diketahui. Oleh karena itu, apabila guru berada di kelas, siswa sebaiknya diberikan kesempatan untuk mengkritisi apa yang sudah dilakukan.

3. Berdasarkan hasil penelitian, siswa berkemampuan matematika rendah cenderung kesulitan ketika memberikan argumen. Oleh karena itu, sebaiknya guru ketika berada dalam kelas selalu mengusahakan untuk memberikan kesempatan kepada siswa dalam memberikan argumen terutama pada siswa dengan kemampuan matematika rendah.

\section{DAFTAR PUSTAKA}

Amala, M. A. (2016). Profil Proses Matematisasi Horizontal dan Vertikal Siswa SMP dalam Menyelesaikan Masalah Kontekstual Pecahan Ditinjau dari Kemampuan Matematika. MATHEdunesa: Jurnal Ilmiah Pendidikan Matematika, 3(5), 300-309.

De Lange, J. (1987). Mathematics, Insight and Meaning: Teaching Learning and Testing of Mathematics for the Life and Sosial Sciences. Utrecht: Vakgroep Onderzoek Wiskundeonderwijs en Onderwijs Computer-centrum (OW \& OC).

Emda, A. (2017). Kedudukan Motivasi Belajar Siswa Dalam Pembelajaran. Lantanida Journal, 173-186.

Freudenthal, H. (2002). Revisiting Mathematics Education. New Delhi: SAGE.

Hadi, S. (2002). Effective teacher professional development for implementation of realistic. Netherland: University of Twente.

Jayanti, M. D. (2018). Kemampuan Pemecahan Masalah Kontekstual Siswa SMA pada Materi Barisan dan Deret. Jurnal Pendidikan: Teori Penelitian, dan Pengembangan, 671-678.

Jupri, A. (2016). Student Difficulties in Mathematizing Word Problems ini Algebra. Eurasia Journal of Mathematics, Science \& Technology Education, 24812502.

Kemendikbud. (2014). Peraturan Menteri Pedidikan dan Kebudayaan Republik Indonesia No 59. Jakarta: Kemendikbud.

Kemendikbud. (2018). Permendikbud Nomor 14 Tahun 2018 Tentang Penerimaan Peserta Didik Baru Pada Taman Kanak-Kanak, Sekolah Dasar, Sekolah Menengah Pertama, Sekolah Menengah Atas, Sekolah Menengah Kejuruan, Atau Bentuk Lain. Jakarta: Kemendikbud. 
OECD. (2009). PISA 2009 Assessment Framework - Key Competencies in Reading, Mathematics and Science. Paris: OECD.

Prediger, S. (2011). Why Johnny Can't Apply Multiplication? Revisiting the Choice of Operations with Fractions. International Electronic Journal of Mathematics Education, 6(2), 65-88.

Putri, F. A. (2018). Profil Matematisasi Horizontal dan Vertikal Siswa SMA dalam Menyelesaikan Soal Program Linier Ditinjau dari Kemampuan Matematika. MATHEdunesa: Jurnal Ilmiah Pendidikan Matematika, 7(3), 578-584.

Ratuman, T. d. (2003). Evaluasi Hasil Belajar yang Relevan dengan Kurikulum Berbasis Kompetensi. Surabaya: Unesa press.

Revina, S. (2019). Skor PISA Melorot, Disparitas dan Mutu Guru Penyebab Utama. Retrieved from Kompas.com:

https://edukasi.kompas.com/read/2019/12/07/1352450 1/skor-pisa-melorot-disparitas-dan-mutu-gurupenyebab-utama?page $=$ all

Rohim, A. (2018). Efektivitas Pembelajaran Di Luar Kelas (Outdoor Learning) Dengan Pendekatan Pmri Pada Materi Spldv. Elektronik Pembelajaran Matematika, 217-229.

Roux, S. (2010). Forms of Mathematization (14th-17th Centuries). Early Science and Medicine, 15, 319-337.
Schoenfeld, A. (2004). The Math Wars. Education Policy, 18(1), 253-286.

Siswono, T. Y. (2010). Penelitian Pendidikan Matematika. Surabaya: UNESA University press.

Suryaningsih, Y. (2017). Pembelajaran Berbasis Praktikum Sebagai Sarana Siswa Untuk Berlatih Menerapkan Keterampilan Proses Sains Dalam Materi Biologi. Bio Education, 49-57.

Uno, H. B. (2008). Orientasi Baru dalam Psikologi Pembelajaran. Jakarta: PT Bumi Askara.

Wardono. (2017). Mathematizing Process of Junior High School Students to Improve Mathematics Literacy Refers PISA on RCP Learning. Journal of Physics, 16.

Warsito. (2018). Improving students' mathematical representational ability through RME-based progressive mathematization. Journal of Physics, 1-6.

Wijaya, A. (2012). Pendidikan Matematika Realistik: Suatu Alternatif Pendekatan Pembelajaran Matematika. Yogyakarta: Graha Ilmu.

Yuniawatika. (2016). Pembelajaran Matematika Di SD Menggunakan Pendekatan Matematika Realistik Indonesia (PMRI). WAHANA SEKOLAH DASAR (Kajian Teori dan Praktik Pendidikan), 22-29.

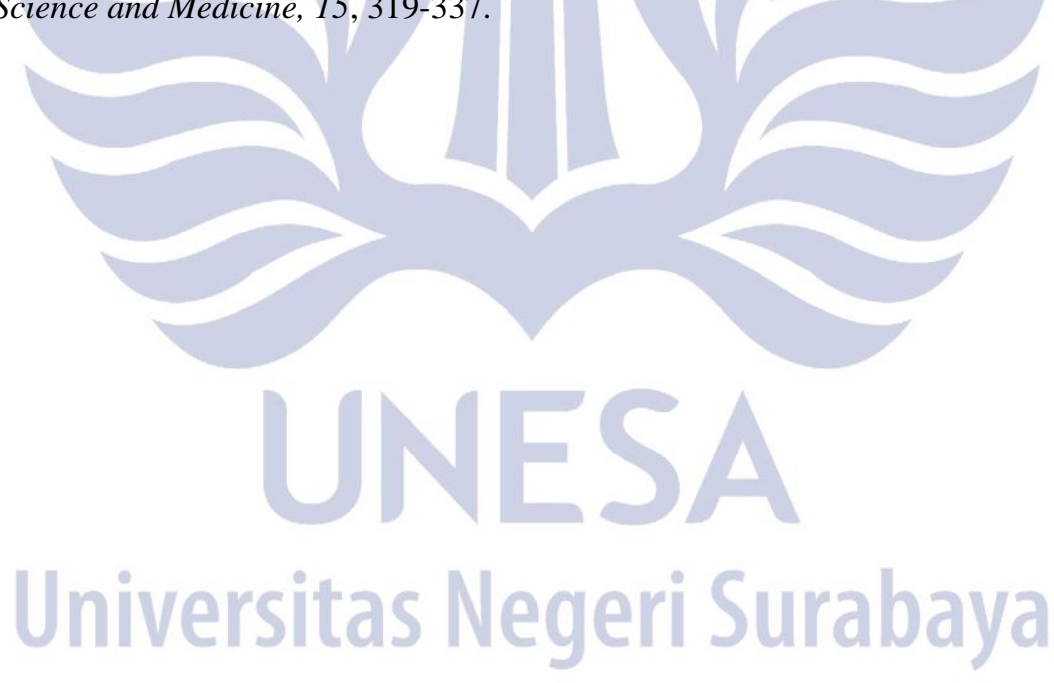

